\title{
Synthesis Study Of Surfactants Sodium Ligno Sulphonate (SLS) From Biomass Waste Using Fourier Transform Infra Red (FTIR)
}

\author{
Slamet Priyanto ${ }^{l}$, Bambang Pramudono ${ }^{l, *}$, Tutuk Djoko Kusworo ${ }^{l}$, Suherman ${ }^{l}$, Hapsoro Aruno Aji ${ }^{l}$, Edi Untoro $^{2}$, Puspa \\ Ratu $^{2}$ \\ ${ }^{1}$ Department of Chemical Engineering, Diponegoro University, Jl. Prof. Soedharto, Tembalang, Semarang, Jawa Tengah, Indonesia \\ 50239 \\ ${ }_{2}^{2}$ Ministry of Energy and Mineral Resources Education and Training Agency (ESDM) Akamigas Cepu Mineral Energy School
}

\begin{abstract}
Lignin from biomass waste (Black Liquor) was isolated by using sulfuric acid $25 \%$ and sodium hydroxide solutions $2 \mathrm{~N}$. The obtained lignin was reacted with Sodium Bisulfite to Sodium Ligno Sulfonate (SLS). The best result was achieved at $80^{\circ} \mathrm{C}, \mathrm{pH} \mathrm{9}$, ratio of lignin and bisulfite 4: 1 , for 2 hours, and $290 \mathrm{rpm}$ stirring rate. The result of lignin formed was sulfonated using Sodium Bisulfite (NaHSO3) to Sodium Ligno Sulfonate (SLS) whose results were tested by the role of groups in peak formation by FTIR and compared to the spectrum of Sodium Ligno Sulfonate made from pure Lignin (commercial) reacted with the commercial Sodium Bisulfite. The result can be seen by the typical functional groups present in the SLS.
\end{abstract}

\section{Introduction}

The waste of pulp and paper industry, called black liquor contains 30-45\% lignin. Lignin from black liquor (Nurhayati, 1993; Gunawan, 2013), potentially produces Sodium Ligno Sulfonate (SLS) surfactant when synthesized with Sodium Bisulfite (Lubis, 2007; Syahbirin, 2012; Qin, 2015). The development of industry in the world is followed by the increasing need of surfactant. Unfortunately, the need for such surfactants is not matched by increased production.

The purpose of the sulfonation process is to change the lignin hydrophilicity by introducing sulfonate groups as hydrophilic groups. Sulfonation process that occurs is reacting lignin with sodium bisulfite (Denli, 2010). The sulfonate group in lignosulfonate makes lignosulfonate to have an amphipatic structure (surfactant). Sulfonates are known by the general formula $\mathrm{R}-\mathrm{SO} 3 \mathrm{Na}$ which is a simplification of R-O-SO3-Na sulfate (Kim, 1987). R is a group of $\mathrm{C} 8-\mathrm{C} 22$ aromatic carbon atoms which were hydrophobic groups, while the hydrophilic group comprises carboxylates, sulphonates, phosphates or other acids5. The sodium lignosulfonate surfactant is categorized in an anionic surfactant because it has a sulphonate group and its salt (-NaSO3-) which is an anion (head) and a hydrocarbon group is the tail (Priyanto, 2017, Ma'ruf, 2017, Syahbirin, 2012).

This research studied the influence of temperature, $\mathrm{pH}$, lignin and bisulfite ratio, time and speed of stirring. The purpose of this research is to get the best sulfonation condition of lignin to SLS. Functional group analysis using FTIR to find out the influencing groups in the SLS. The study of each influential variable was applied to find out the combined variables of this synthesis process.

\section{Experimental}

\subsection{Materials}

Lignin from Black Liquor was purchased from PT. Indah Kiat Pulp and Paper Factory at Pekanbaru, Riau, West Sumatra, Indonesia. Lignin was isolated from black liquor by acidifying it with $25 \%$ sulfuric acid solution. Lignin was synthesized by sodium hydroxide $20 \% \mathrm{w} / \mathrm{w}$ solution with $\mathrm{pH} 9,5$ dried at $60^{\circ} \mathrm{C}$ for 6 hours and to mesh size of $60-80$. Sulfuric acid, sodium hydroxide and demineralized water (aquadest) obtained from PT. Indra Sari Semarang, Central Java, Indonesia.

\subsubsection{Sulfonation Of Lignin and Synthesis Process of SLS}

This phase is the core stage to produce salt lignosulfonates. The reaction occurs between the lignin which has been acidified with sulfite salt (Denli, 2010). There are several types of salt sulphites which can be used in the sulfonation. In US Patent No.4,892,588 sulphite salt used is sodium bisulfite (Rahmawati, 1999; Salminah, 2001).

Two grams of lignin from black liquor was reacted with $2.0 \mathrm{ml} 40 \%$ bisulfite solution and $60 \mathrm{ml}$ aquadest. Temperature was adjusted from 50 to $95^{\circ} \mathrm{C}, \mathrm{pH}$ from 7 to 10 , time from 1 to 4 hours, ratio of lignin and bisulfite from 2 to 5 , and the rate of stiring from 250 to $310 \mathrm{rpm}$. SLS liquid phase was evaporated at a temperature of

Corresponding author: pramudono2004@yahoo.com 
$100^{\circ} \mathrm{C}$. The concentrated solution formed was then filtered through a buchner funnel using a vacuum pump.

The filtrate obtained is SLS containing lignin and residual bisulfite. The filtrate was mixed with methanol to precipitate an insoluble bisulfite, shaken vigorously, and further filtered with a buchner funnel. The SLS filtrate and residual lignin were evaporated to concentrate the SLS. The obtained concentrated SLS was dried at $60^{\circ} \mathrm{C}$ to a constant weight, this is the yield to be analysed by the role of the group with FTIR.

\subsubsection{Characterization Methods}

FT-IR spectrophotometer (SHIMADZU with DRS-8000) was used to analyze the Infrared spectroscopy using a $\mathrm{KBr}_{\text {pellets }}{ }^{6}$. The $\mathrm{KBr}$ pellets consist of $300 \mathrm{mg} \mathrm{KBr}$ and $0.1 \mathrm{mg}$ fine powder of SLS sample. Scans were recorded from 400 to $4000 \mathrm{~cm}^{-1}$ at a resolution of $16 \mathrm{~cm}^{-1}$.

\section{Results and Discussion}

\subsection{Effect of Process Variables}

Figure 1 illustrates the effect of variables temperature, $\mathrm{pH}$, lignin and bisulfite ratio, time and rate of stiring on the yield of SLS. Based on Table 1, it can be seen that the best value for yield at $94 \%$ was reached at the temperature of $80^{\circ} \mathrm{C}, \mathrm{pH} 9$, ratio of lignin and bisulfite 4 , time of 2 hours and the rate of stiring of $290 \mathrm{rpm}$.

Table 1. The best conditions of SLS yield

\begin{tabular}{|c|c|}
\hline \multicolumn{2}{|c|}{ The best value; Variable: Yield at $94 \%$} \\
\hline Variables & Best Condition \\
\hline Temperature, ${ }^{\circ} \mathrm{C}$ & 80 \\
$\mathrm{pH}$ & 9 \\
Ratio, $\mathrm{g} / \mathrm{g}$ & 4 \\
Time, hour & 2 \\
Rate of stiring, rpm & 290 \\
\hline
\end{tabular}

Table 2 shows the national standardization of Indonesia (SNI) characteristics of SLS from waste Lignin.

Table 2. Characterization of SLS yield

\begin{tabular}{|c|c|c|c|c|c|}
\hline $\mathrm{Nu}$ & Parameter & Unit & $\begin{array}{l}\text { SLS } \\
\text { Ref }\end{array}$ & $\begin{array}{l}\text { SLS from } \\
\text { Waste }\end{array}$ & Method \\
\hline 1 & Water content & 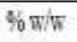 & 23.96 & 24.62 & SNI 2012-0813-122059 \\
\hline 2 & Ash Content & $\% w / \%$ & 31.78 & 32.23 & SNI 1247-0442-2009 \\
\hline 3 & Organic compounds & $\% \pi / w$ & 39.97 & 41.76 & SNI 03-2831-1992 \\
\hline 4 & Volatile Matter & $\% \pi / w$ & 4.98 & 5.14 & SNI 13-3999-1995 \\
\hline 5 & Density (solid) & gmi & 1.09 & 1.12 & SNI 06-2441-1991 \\
\hline
\end{tabular}

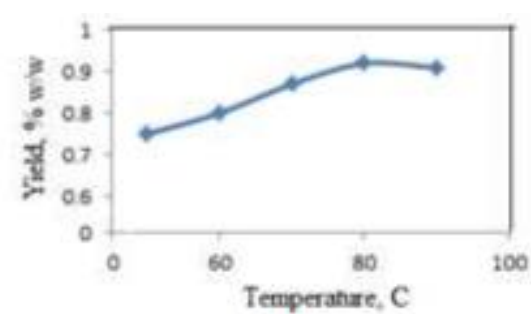

(a)

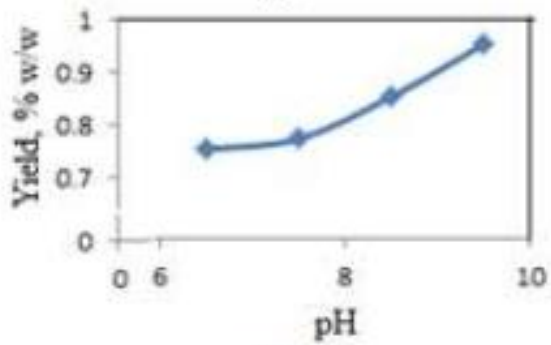

(b)

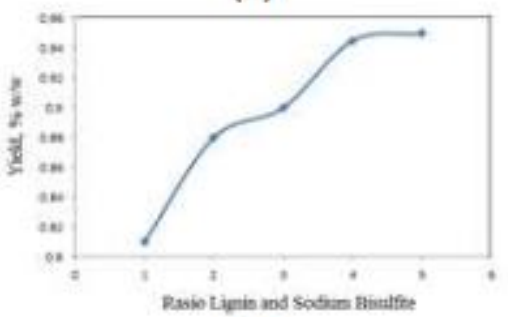

(c)

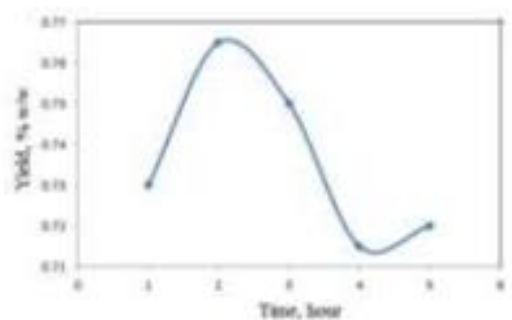

(d)

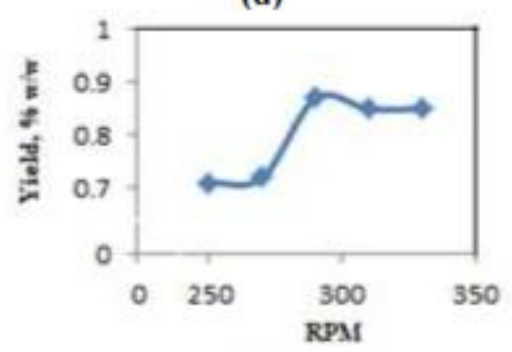

(e)

Fig. 1. Effect of temperature (a), pH (b), lignin and bisulfite ratio (c), time (d) and rate of stirring (e) on the yield of SLS

\subsection{FT-IR Characteristics of SLS from waste lignin and Pure SLS}

Figure 2 shows the spectra of Reference SLS obtained (blue line) and the spectra of SLS from waste lignin (red line). The band between $3425.88-3541.1 \mathrm{~cm}^{-1}$ is typical of hydroxyl groups (O-H stretch) in phenolic and aliphatic structures. The peak at 2337.72; 2361 and $2337.72 ; 2360.87 \mathrm{~cm}^{-1}$ indicated a sp ${ }^{3}$ C-H MS stretching in methyl $\left(-\mathrm{CH}_{3}\right)$, methylene $\left(=\mathrm{CH}_{2} /-\mathrm{CH}_{2}-\right)$ and methoxy $\left(-\mathrm{OCH}_{3}\right)$ groups ${ }^{6}$. The peak at 1512.19, 
1564.34, 1512.19, 1635.14 indicated groups of $\mathrm{C}-\mathrm{H}$ AS5. In the sulfite $\left(\mathrm{SO}_{3}\right)$ region, a weak band is found at $1450.47 \mathrm{~cm}^{-1}$ (blue line) and 1450.57 (red line). Furthermore, the $\mathrm{S}-\mathrm{O}, \mathrm{S}=\mathrm{O}, \mathrm{SO}_{3}, \mathrm{C}-\mathrm{H}$, and $\mathrm{OH}$ role of the group in peak formation can be seen in Table-7 (Prakosa, 2017, Ma'ruf, 2017).

Tabel 3. The role of group in SLS

\begin{tabular}{|c|c|c|c|c|}
\hline \multirow[t]{2}{*}{ Group } & \multicolumn{2}{|c|}{ SLS Refiktence (Bloe) } & \multicolumn{2}{|c|}{ SLS from Waste Lignin (Red) } \\
\hline & Peak-1 & Peak-2 & Pess.1 1 & Peak-2 \\
\hline $5-0$ & $<964$ & - & - & - \\
\hline s-o & 964.41 & - & 9489 & - \\
\hline 5.0 & 1033.85 & - & 1041.56 & - \\
\hline$s=0$ & IIII & - & 1111 & - \\
\hline $\mathrm{SOH}$ & 1450.47 & - & 145057 & - \\
\hline C.HAS & 1512.19 & 1564,34 & 1512.19 & 1635.14 \\
\hline C.HMS & 2337,72 & 2361 & 2337.72 & 2360.87 \\
\hline $\mathrm{OH}$ & 342588 & - & 3541.1 & - \\
\hline CH & $>3600$ & - & $>3400$ & . \\
\hline
\end{tabular}

The band at $1512.19 \mathrm{~cm}^{-1}$ is a typical aromatic skeleton vibration combined with $\mathrm{C}-\mathrm{H}$ in plane deformations, while 1564.34 and $1635.14 \mathrm{~cm}^{-1}$ is of aliphatic $\mathrm{C}-\mathrm{H}$ stretching in $\mathrm{CH}_{3}$ (not $-\mathrm{OCH}_{3}$ ) and phenolic $-\mathrm{O}-\mathrm{H}$. The band at 1450.47-1450.57 $\mathrm{cm}^{-1}$ shows $\mathrm{SO}_{3}$. The band at $1111 \mathrm{~cm}-1$ and at 964.41$1033.85 \mathrm{~cm}^{-1}$ (blue line) and at $1033.85 \mathrm{Cm}^{-1}$ in SLS reference, at $1041 \mathrm{~cm}^{-1}$ in SLS from waste lignin (Prakosa, 2017). FT-IR spectra indicate the spectral features of SLS that are the band at 964.41 and 1450.57 $\mathrm{cm}^{-1}$. The aromatic S-O deformation at $948.9 \mathrm{~cm}^{-1}$ and $\mathrm{S}-\mathrm{O}$ at $1041.56 \mathrm{~cm}^{-1}$ appear as aromatic $\mathrm{SO}_{3}$ at 1450.47 and $1450.57 \mathrm{~cm}^{-1}$ or $<964 \mathrm{~cm}^{-1}$.

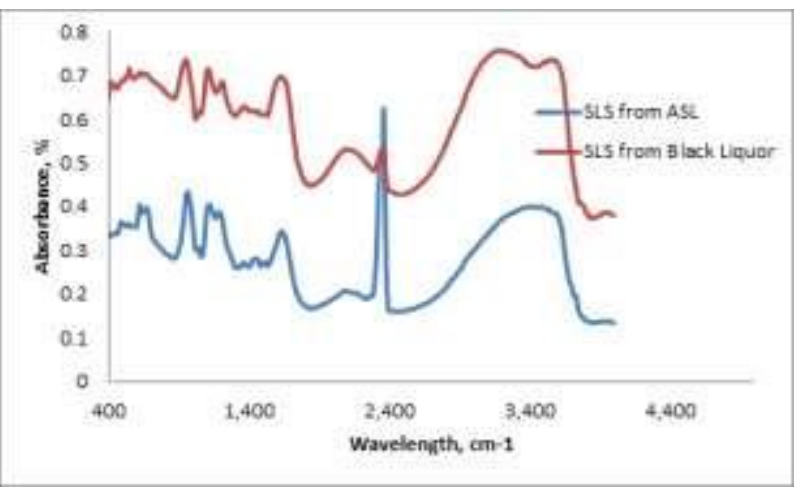

Fig. 2. FT-IR spectra of SLS Reference (blue) and SLS from waste (red)

\section{Conclusion}

Sodium lignosulfonate (SLS) can be prepared by reacting lignin derived from black liquor biomass waste under best conditions of the temperature of $80^{\circ} \mathrm{C}, \mathrm{pH}$ of 9-9.5, the weight ratio of lignin and bisulfite of 4.00, time of 2 hours, and the rate of stiring of $290 \mathrm{rpm}$, to obtain the highest yield of SLS $94 \%$.

This study was supported by Ministry of Research,Technology and High Education Fiscal Year 2017, No:345-22 / UN7.5.1 / PG / 017

\section{References}

1. Nurhayati, T., R.A. Pasaribu, Journal of Forest Product Research 11, 3, 110-116 (1993)

2. Gunawan, D., Scientific Article 1, 1 (2013)

3. Lubis, A.A., Isolation of Lignin From Black Liquor Process Cooking Soda Pulp And Pulp Sulphate (Kraft), (Isolasi Lignin Dari Lindi Hitam (Black Liquor) Proses Pemasakan Pulp Soda Dan Pulp Sulfat (Kraft), Thesis of Faculty of Agriculture, IPB, Bogor (2007)

4. Syahbirin, G., Darwis, A.A., Suryani, A. Syafii, W., 2012, Procedia Chem. 4, 343 (2012).

5. Qin, Y., Yang, D., Guo, W., and Qiu, X., J. Ind. Eng. Chem. 27, 192 (2015).

6. Denli, The Conversion of Lignin to Surfactant (Konversi Lignin Menjadi Surfaktan), Thesis of Faculty of Agriculture, IPB, Bogor (2010)

7. Kim, H., M.K. Hill, A.L. Fricke, Tappi Journal 12, 112-115 (1987)

8. Priyanto, S., Suherman, Istadi, Nugroho, A., Aji, H.A., Advanced Science Letters 23, 6, 58035805 (2017)

9. Ma'ruf, A., Pramudono, B., Aryanti, N., Rasayan, J. Chem., 10, 2, 407 (2017)

10. Rahmawati, N., Lignin Structure of Lumber Leaf Width and Its Influence on Delignification Rate (Struktur Lignin Kayu Daun Lebar dan Pengaruhnya terhadap Laju Delignifikasi), Thesis of Graduate Program Bogor Agricultural University, Bogor (1999)

11. Salminah, M., Characteristics of Lignin Result Isolation of Cooking Time Solution Pulp SemiChemical Process at Various Levels of $\mathrm{pH}$ (Karakteristik Lignin Hasil Isolasi Larutan Sisa Pemasak Pulp Proses Semi Kimia pada Berbagai Tingkat $p H$ ), Thesis of Department of Forest Products Technology Faculty of Forestry, Bogor Agricultural University. Bogor (2001)

12. Prakoso, N.I., Purwono, S., Rochmadi, AIP Conf. Proc. 1823, 1 (2017) 